\title{
Correspondence:
}

\section{Cutaneous aspergillosis in a patient with diabetes mellitus}

A 67-year-old male patient known to have diabetes mellitus for the past 10 years presented with a swelling near the left elbow joint. He was human immunodeficiency virus (HIV) seronegative. Fine needle aspiration cytology (FNAC) (Figure 1) showed an acute inflammatory exudate suggestive of an infectious aetiology. On Gomori's Methenamine Silver (GMS) (Figure 2) and periodic acid Schiff(PAS) stains (Figures 3 and 4) slender, elongated, septate fungal hyphae with dichotomous branching with fruiting bodies suggestive of acrospores ${ }^{1}$ were evident, suggestive of cutaneous aspergillosis.

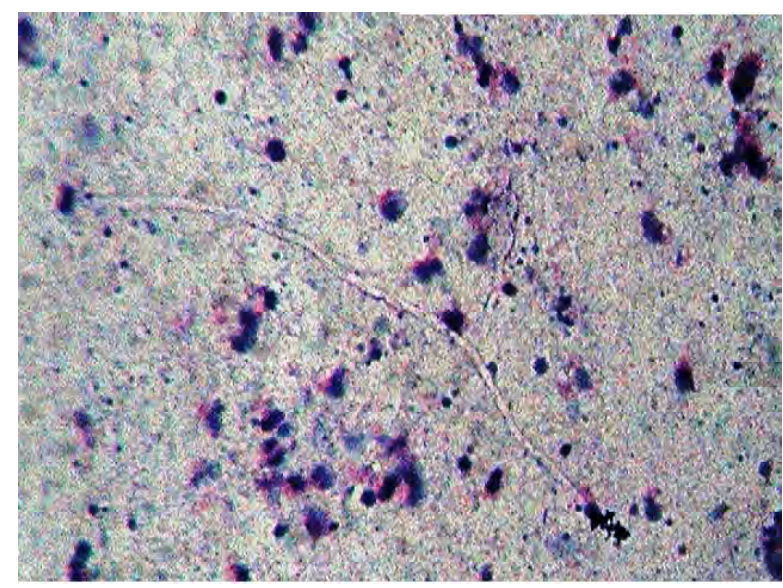

Figure 1: Photomicrograph showing an unstained form of aspergillus and acute inflammatory exudate with (Haematoxlin and eosin, $\times 400$ )

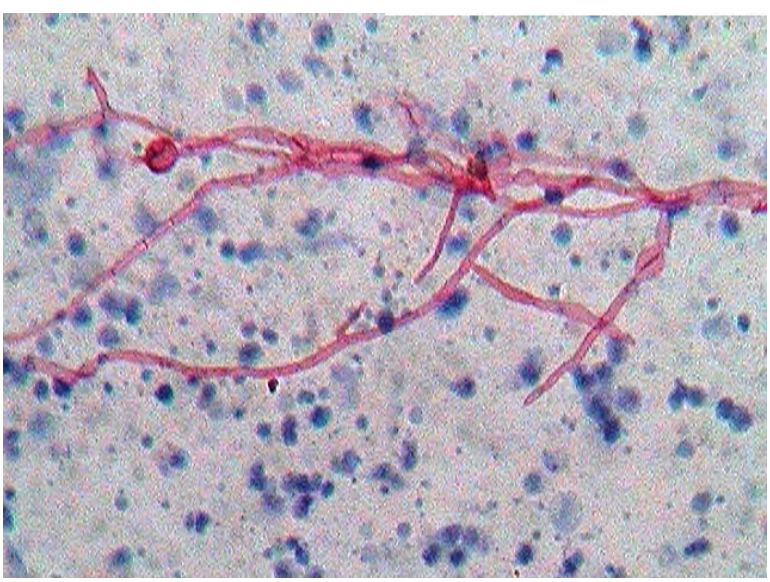

Figure 3: Photomicrograph showing aspergillus with slender septate hyphae branching at acute angulation and fruiting body at an end (Periodicacid Schiff, $\times 400$ )
The most common sites of presentation of aspergillosis are lung and paranasal sinuses, otomycosis and keratitis are also less frequently located. ${ }^{2}$ Cutaneous aspergillosis is a rare condition that is usually seen among immunocompromised patients. Cutaneous aspergillosis frequently is a feature of acute disseminated aspergillosis due to the angiopathic nature of the organism, ${ }^{3}$ and is evident in 5\%-10\% of patients with disseminated aspergillosis. ${ }^{4}$ In this report we document the exceptionally rare occurrence of isolated cutaneous aspergillosis. Further more, our case is also unique in that "fruiting bodies" were identified on FNAC examination. The fruiting bodies are not usually

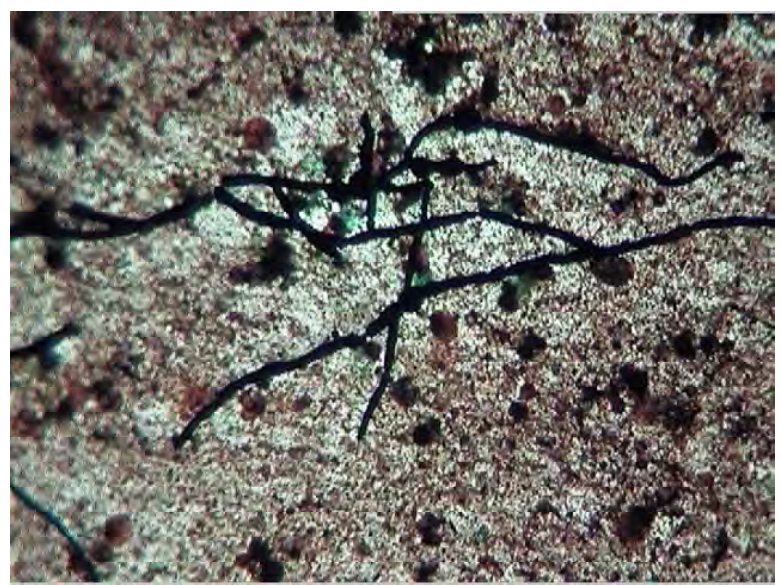

Figure 2: Photomicrograph showing slender septate hyphae of aspergillus with dichotomous branching (Gomori Methenamine Silver, $\times 400$ )

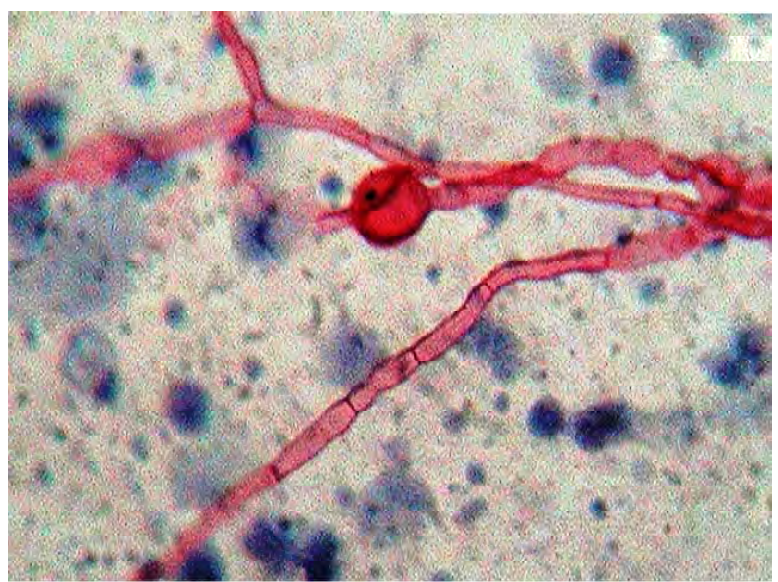

Figure 4: Photomicrograph showing a closer view of fruiting body and septate branching hyphae of aspergillus (Periodic acid Schiff, $\times 1000$ ) 
picked up even in tissue biopsies, unless there is an overwhelming number of organisms at the site. ${ }^{5}$

\section{REFERENCES}

1. McAdam AJ, Sharte AH. Infectious diseases. In: Kumar V, Abbas AK, Fausto N, Aster JC, editors. Robbins and Cotran pathologic basis of disease. 8th edition. New Delhi: Saunders Elsevier; 2010.p.384-5.

2. Müller FM, Trusen A, Weig M. Clinical manifestations and diagnosis of invasive aspergillosis in immunocompromised children. Eur J Pediatr 2002;161:563-74. Epub2002 Sep 11.
3. Denning DW. Aspergillosis. In: Fauci AS, Braunwald E, Kasper DL, Hauser SL, Longo DL, Jameson JL, et al, editors. Harrison's principles of internal medicine. 17th edition. New York: McGrawHill and Companies Inc.; 2008.p. 1258.

4. Ozer B, Kalaci A, Duran N, Dogramaci Y, Yanat AN . Cutaneous infection caused by Aspergillus terreus. J Med Microbiol 2009;58:968-70.

5. Ritter JH, Krigman HR. Lung. In: Humphrey PA, Dehner LP, Pfeifer JD, editors. The Washington manual of surgical pathology. 2nd edition. New Delhi: Wolters Kluwer /Lippincott Williams and Wilkins; New Delhi: 2012.p.105-48.

K. Radhika,

K. Sameera,

B.V. Phaneendra.

Department of Pathology

Sri Venkateswara Institute of Medical Sciences,

Tirupati

Received: 03 September, 2012.

Radhika K, Sameera K, Phaneendra BV. Cutaneous aspergillosis in a patient with diabetes mellitus. J Clin Sci Res 2013;2:46-7. 